\title{
THE APPROPRIATE RESPONSE
}

\section{Class war.}

\section{BY JEFF SAMSON}

$\mathrm{T}$ he last line rolled off the teacher's tongue. He turned from the wall displaying the poem and a portrait of its author, and looked at his students.

His eyepieces engaged immediately. Above a scattering of raised hands, each student's name burst into the air in bold, translucent blue characters.

As mandated, he ignored the customary hands, giving the less impetuous students ample processing time. He scanned the room, eyes moving from seat to seat, his gaze triggering the name hovering above each head to lift towards the ceiling, leaving a detailed profile in its wake.

"Mr Papillon," he said, and paused.

John Papillon — a socially challenged Level 3 with anger issues, who was never to be corrected or forced to maintain eye contact for longer than 6.5 seconds - shifted in his seat. Above his head, the details of his Individualized Cognition Enhancement Dossier - his ICED - were pushed left by a selection of questions that slid into position from empty space. The teacher chose the third.

"Mr Papillon," he read, "would you please be so kind as to recite the second word in the third line of the fourth stanza for us?"

The student squinted up at the poem, counting down and over with an outstretched finger, his tongue extended with effort.

"Home," he said.

The teacher turned and read the second word in the third line of the fourth stanza - hope. He turned back to John Papillon, as the profile and list of questions both slid left to be replaced by directions on how to respond to this student if - as was likely - he had misread his word. These too, the teacher read.

"Mr Papillon, you have correctly given us the third word of the fourth line of the second stanza. It is indeed 'home'. And it is entirely understandable that you selected the word you did, seeing as I threw quite a bit of information at you at once."

He paused as the warning light flashed, telling him to look away. He broke, then resumed eye contact.

"And on top of that, the word 'hope' is extremely close to the word 'home'. In fact, there is only one letter that makes them different. Well done, Mr Papillon."

He smiled for a calculated interval at the student, who stared back at him through

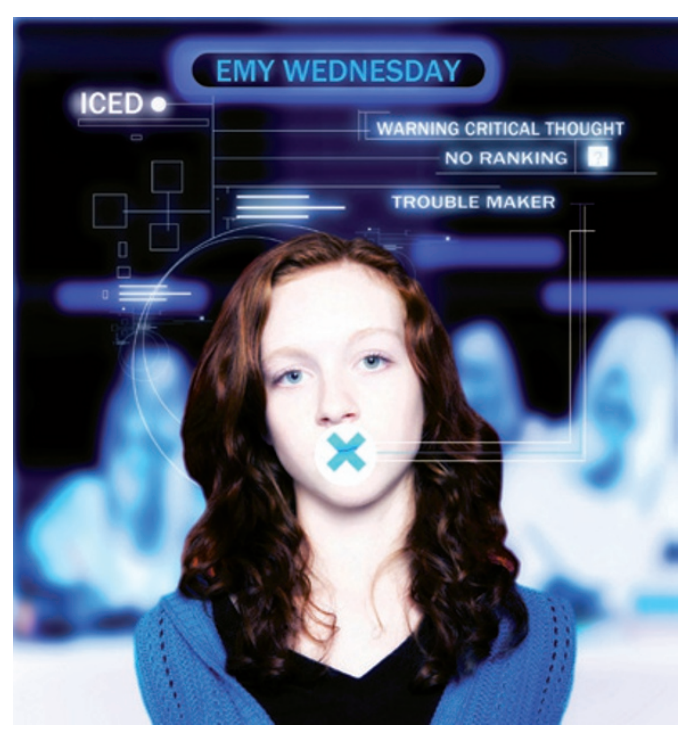

doorway, in which stood what seemed to 立 be a bearded old man vomiting onto the pavement.

Before the response slid into position, a third student, whose waving hand the teacher had steadfastly ignored, broke the silence.

"Bullshit!" she cried.

The teacher whipped his head around. He stared into the smoldering eyes of Emy Wednesday - a troublemaker whose cognitive deficiencies eluded numerical ranking but indicated an inclination towards critical thought, and an utter disregard for the self-esteem and unfairly distributed abilities of her peers. Her hands were pressed to her desk, balled up in tight fists.

"Total bullshit!"

The teacher stood, silent, gazing at the space above her head, waiting for glassy, half-lidded eyes. When the teacher turned away, the menus above John Papillon collapsed and his name fell back in line.

The teacher paused at Heidi Devendorf a timid Level 4 with an acute fear of vowels, who was never to be asked to read aloud. A deep red light framed her profile, indicating that she'd already filled her allotted participation time for the week.

He stopped next at Seth Nozarski - a parentally inflated Level 8, who was to be kept at a minimum distance of seven feet from any student with freckles. But the violet glow rimming his profile told the teacher Seth's selfassuredness was running unhealthily low, and that he'd be best left alone.

He continued his scan and eventually called on Arthur Fink - an artistically inclined Level 15 with a flair for abstract thinking, who was entitled to submit illustrations in lieu of essays and exams.

"Mr Fink," he said. The student jolted upright in his seat. "What do you think the title, Crossing the Bar, means?"

The student craned his head upwards, closing his eyes. He then crouched over his desk and began furiously scribbling with his stylus on his EdPad. Two minutes later, the student slammed down his stylus and spun the EdPad around to face the teacher. What he displayed, left to right, was a crude sketch of a cross, followed by "+ ing + the +" in sloppy letters. Next $\rightarrow$ NATURE.COM to this was a rudimenFollow Futures on tary façade of a buildFacebook at: ing bearing the name go.nature.com/mtoodm 'Murphy's Pub' above a a response to appear. But she still kept screaming.

"The title is a metaphor for death! The

He waited.

"It's about an old man accepting his death and not wanting those he leaves behind to mourn him when he's gone!"

And waited.

"And you're going on about naming this goddamn word in this goddamn stanza!" she cried, jabbing her finger into the charged air between them. "And -"

They burst into the room, two disciplinarians clad in black, weaving through the desks, seizing Emy as she flailed and fought, dragging her writhing body out into the hallway as she screamed about death and the old man.

When the door closed behind them, the teacher turned back to his class and wiped away the lone bead of sweat trickling down his forehead.

"I apologize for the disruption," he said. "Now, where were we?"

He turned back to Arthur Fink, who still held the EdPad up for him to see, his expression earnest. The space above the student's head returned to life, and after a few short moments, revealed fat, shimmering letters. read.

\section{"Brilliant." -}

Jeff Samson brews Irish stout when he's not writing science fiction, and often drinks it when he is. He lives in New Jersey with his wife and baby girl, and no cats. whole poem's about death!" The teacher paused. Smiled proudly. And 